補綴誌, J Jpn Prosthodont Soc, 43:335〜343, 1999.

\title{
原著論文
}

\section{新規シリコーンラバー系軟質裏装材デンチャーリライニングと 各種床用材料との接着強さ}

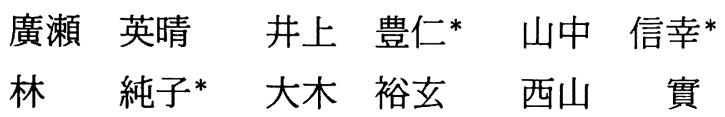

A Study on Tensile Bond Strength of Silicone-rubber Soft Relining Material : Denture Relining ${ }^{\circledR}$ to Various Denture Base Materials

Hideharu Hirose, Toyonori Inoue*, Nobuyuki Yamanaka*, Junko Hayashi*, Yugen Ohki and Minoru Nishiyama

\begin{abstract}
The tensile bond strength (TBS) to denture base materials of silicone-rubber soft relining materials (DRS : Denture Relining Soft type, GC) immersed in water at $37^{\circ} \mathrm{C}$ from 1 day to 8 weeks was investigated. Four denture base metals ( $18 \mathrm{~K}-\mathrm{Au}$ alloy, $\mathrm{Ag}-\mathrm{Pd}-\mathrm{Au}$ alloy, $\mathrm{Co}-\mathrm{Cr}$ alloy and $\mathrm{Pure} \mathrm{Ti}$ ) and two denture base resins (polycarbonate resin and polysulfon resin) were used. The TBS of DRS was $1.39 \sim 2.05$ $\mathrm{MPa}$ to denture base metals and $1.59 \sim 1.81 \mathrm{MPa}$ to denture base resin after 1-day immersion, and $1.59 \sim 2.75$ $\mathrm{MPa}$ and $1.47 \sim 2.33 \mathrm{MPa}$ respectively after 8 -week immersion. These values were significantly superior to those of two ordinary silicone-rubber relining materials.
\end{abstract}

Key words : denture relining, silicone-rubber soft relining material, tensile bond strength, denture base metal, denture base resin

\section{I. 緒言}

義歯床裏装材には，硬質裏装材と軟質裏装材（弾性裏装 材）とがある。このうち，軟質裏装材は，主として，骨縁 が細く鋭い歯槽堤や菲薄で柔軟性のない粘膜に覆われた歯 槽堤を有する症例に発現しがちな咀嚼時の疼痛を緩和する ための緩衝材として，また，咬合圧の均等分散を目的とし て用いられている1 13).

近年, 高齢化社会の進展に伴い, 義歯装着患者の急速な 増加とともに軟質裏装材の適用例は, 増加の傾向を示して

日本大学歯学部菌科理工学教室 (主任：西山 嘪教授)

-日本大学歯学部附属歯科技工専門学校（校長：五十嵐孝義教授）

Department of Dental Materials, Nihon University School of Dentistry (Chief : Prof. Minoru Nishiyama)

* Dental Technician Training School, Nihon University School of Dentistry (Principal : Prof. Takayoshi Igarashi)

平成 10 年 11 月 30 日受付
いる. しかし，軟質裏装材使用後の予後調査結果では，予 後不良の要因として「弾性の劣化」および「色調の劣化」

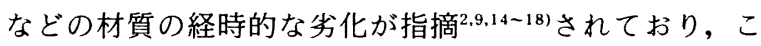
の種の材料は, 口腔内における耐久性の向上が必須と考え られた。

前報 ${ }^{19)}$ では，口腔内での耐久性の改善を図ったとされる 新しいシリコーンラバー系軟質裏装材デンチャーリライニ ング(ソフト：DRS およびミディアム：DRM，ジー シー）の物性および義歯床用アクリルレジンとの接着強さ の経時的変化について, $37^{\circ} \mathrm{C}$ 水中に 1 日〜 5 力月間浸漬し て検討した。 また，義歯洗浄剤溶液に 1 力月浸漬したのち の接着強さについても検討した. その結果, DRS および DRM の引張強さは, 経時的に増加し, 5 力月後でそれぞ れ 3.81 および $4.37 \mathrm{MPa}$ を示すこと, DRS およびDRM の引裂強さは, 経時的にはほとんど変化がなく, 5 力月後 でそれぞれ 11.14 および $9.22 \mathrm{kN} / \mathrm{m}$ を示すこと, DRS お よび DRM の接着強さは, 経時的に増加し, 5 力月後でそ 
れぞれ 3.83 および $2.82 \mathrm{MPa}$ をすこと，また，中性過 酸化物を含む酵素系義歯洗浄剤では，DRM の接着強さを 低下させないこと，などを報告した。

そこで，本研究では，上記の検討にひきつづき，義歯床 用アクリルレジン以外の義歯床用材料，すなわち，義歯床 用金属および義歯床用レジンとの接着強さの経時的変化を 測定して，デンチャーリライニングの有用性について検討 することとした。なお，対照として在来品 2 種類も加え た.

\section{II. 材料および方法}

\section{1. 材料}

表 1 に，使用した軟質裏装材およびプライマーを，表 2 に，使用した義歯床用材料を示した。なお，各材料につい て以下文中ではコードで表示した.

\section{2. 方法}

1）被着体試料の調製

（1）金属被着体

$\phi 12 \times 1.5 \mathrm{~mm}$ のパラフィンワックスを通法に従い, 埋 没・焼却後，鋳造した。鋳造には $18 \mathrm{~K}, \mathrm{AG}$ および CO で は吸引加圧式鋳造機（アルゴンキャスター $\mathrm{T}$ ，松風）を， TIでは遠心鋳造機（タイキャストスーパーR，コベルコ

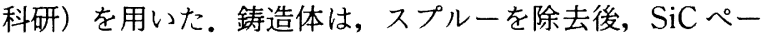
パー\#600を用いて湿式で研磨して仕上げた。

(2) レジン被着体

PC およびPSF は，製造者指示に従って成型器を用い，
それぞれ射出成形または加熱加圧成形して $\phi 12 \times 1.5 \mathrm{~mm}$ の円盤状に成形した。成形体は，型から取り出した後, $\mathrm{SiC}$ ペーパー\# 600 を用いて湿式で研磨して仕上げた。

以上で調製した被着体試料をそれぞれ真鍮製支持棒 $(\phi 12 \times 28.5 \mathrm{~mm})$ に接着（接着剤：アロンアルファ，東 亜合成）し，それらを接着強さ測定用被着体（ $\phi 12 \times 30$ $\mathrm{mm}, 2$ 本 1 組）とした。

2）接着試験体の作製

（1）試験体の作製

図 1 に，接着試験体の模式図を示した. 接着試験体の作製は以下のように行った。

すなわち，接着時に被着体を固定する透明アクリルレジ ン製ガイドリング（内径 $12 \mathrm{~mm}$ ，外径 $16 \mathrm{~mm}$ ，高さ 60 $\mathrm{mm}$ ) の内面に分離材（信越バリアコートNo.6, 信越化 学工業）を塗布した。次に，被着体の端面（直径 12 $\mathrm{mm}$ ）にプライマーDRP を塗布し，5 分間放置して自然乾

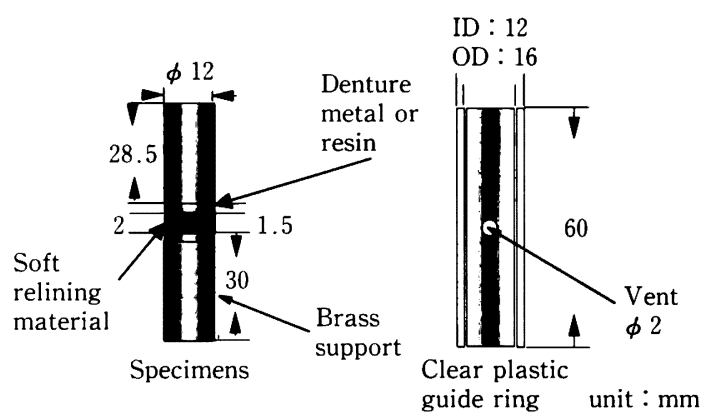

図 1 Specimen and it's guide ring for preparation 接着試験体およびガイドリング

表 1 Soft relining materials used in this study 軟質裏装材

\begin{tabular}{llllr}
\hline \hline Code & \multicolumn{1}{c}{ Soft relining material } & \multicolumn{1}{c}{ Primer } & Manufacturer & Lot No. \\
\hline \multirow{2}{*}{ DRS } & Denture Relining (Soft type) & Primer for Denture Relining (DRP) & GC & 100371 \\
ETH & EVATOUCH H TYPE & ADHESIVE & NEO DENTAL PRODUCT & 100471 \\
TSR & TOKUYAMA SOFT RELINING & Primer & TOKUYAMA & 910410 \\
& & & & 59866 \\
\hline
\end{tabular}

表 2 Denture base materials used in this study 義歯床用材料

\begin{tabular}{|c|c|c|c|c|}
\hline Code & Material & Name or type & Manufacturer & Lot No. \\
\hline $18 \mathrm{~K}$ & $75 \mathrm{Au}-15 \mathrm{Cu}-7 \mathrm{Ag}-2 \mathrm{Pd}$ alloy & K.18 M.C. GOLD ALLOY & GC & $\begin{array}{l}201151 \\
060171 \\
141071\end{array}$ \\
\hline$A G$ & $\mathrm{Ag}-\mathrm{Pd}-\mathrm{Au}$ alloy & Castwell M.C. 12\% Gold & $\mathrm{GC}$ & 290571 \\
\hline $\mathrm{CO}$ & $\mathrm{Co}-\mathrm{Cr}$ alloy & Biosil 1 & DEGUSSA & 5968191 \\
\hline TI & Titanium & JIS-type 2 & SELEC & $\mathrm{K}-96-11$ \\
\hline $\mathrm{PC}$ & Polycarbonate resin & $\begin{array}{l}\text { Denture base } \\
\text { polycarbonate resin } \\
\text { SR } 320\end{array}$ & Tohshin Yoko & QDE $17 \mathrm{~T}$ \\
\hline PSF & Polysulfone resin & UB Preform & SANKIN & 705273 \\
\hline
\end{tabular}


燥させたのち, 被着体の 1 本をガイドリング中にセット し, 被着体のプライマ一塗布面に DRS 練和ペーストを ディスペンサーから注入し, 直ちに, もう 1 本の被着体を 挿入した。次に, DRS ペーストを挟んだ被着体およびガ イドリングを一体として固定用治具 ${ }^{19}$ に装着し，ボルトで 被着体両端からプレスして DRS 層の厚みを $2 \mathrm{~mm}$ として 固定したのち, 固定用治具ごと $37^{\circ} \mathrm{C}$ 水中に 5 分間浸漬し てDRS を硬化させた. 水中浸漬後, 固定用治具ごと水中 から引き上げて, 治具およびガイドリングから軟質裏装材 と試料の接着体を取りはずした，取り出した接着体を，再 度 $37^{\circ} \mathrm{C}$ 水中に下記の所定期間浸漬したものを接着強さ測 定用試験体とした。

一方, 対照の軟質裏装材 ETH およびTSRの試験体 は, それぞれの製造者指示に従ってプライマーの塗布処理 および練和したのち，上記と同様にして作製した。

(2) 浸漬期間

試験体の $37^{\circ} \mathrm{C}$ 水中浸漬期間は，1日 (24 時間)，1，2， 4,6 および 8 週間とした.

（3）接着強さの測定方法

測定には, 万能試験機（TCM-5000 A：ミネベアおよ び 5567 型：インストロン) を用いクロスヘッドスピード $10 \mathrm{~mm} / \mathrm{min}$ で引張試験を行った。

試験体数は, 各材料とも所定の浸漬期間につきそれぞれ 5 個ずつとし, 得られた平均を接着強さとした.

上記の試験体の作製および測定は, 室温 $23 \pm 1^{\circ} \mathrm{C}$, 相対 湿度 $50 \pm 5 \%$ の環境下で行った。

(4) 破壊様式の観察

接着強さ測定後の破壊した試験体については，その破壊 様式を知るために，ルーぺ（倍率 10 倍）を用いて破断面 を観察した．破壊様式の判定は，界面の露出が $80 \%$ 以上 を界面破壊，軟質裏装材の付着が $80 \%$ 以上を凝集破壊， そのいずれにも属さないものを混合破壊として分類した。

\section{III. 結 果}

表 3 に, $37^{\circ} \mathrm{C}$ 水中に浸漬した接着強さの経時的変化を 示し, あわせて 8 週間浸漬後の 3 種の軟質裏装材間での接 着強さの $\mathrm{t}$-検定結果を示した。表 4 に, 浸漬期間ごとの接 着強さの $\mathrm{t}$-検定結果を示した.

\section{1. $18 \mathrm{~K}$ との接着強さ}

表 3 および図 2 に, 各軟質裏装材と $18 \mathrm{~K}$ との接着強さ の経時的変化を示した.

DRS の接着強さは, 浸漬 2 週間後までは $2.1 \mathrm{MPa}$ 前後 のほほ一定した値を示した後増大し，4〜8週間後では 2.8 $\mathrm{MPa}$ 前後のほほ一定した値を示した。

対照の ETH の接着強さは, 浸漬 1 日後では $0.05 \mathrm{MPa}$ を示したが, 1 週間後以降では引張試験前に剥離を示し,
$0 \mathrm{MPa}$ となった. また, TSR の接着強さは, 経時的に浸 漬 1 日から 8 週間後まで変動が認められ，0.54〜0.76 $\mathrm{MPa}$ を示した.

また，浸漬 8 週間後での各軟質裏装材の接着強さを比較 すると, DRSのそれが，ETH およびTSRのそれより有 意（危険率 $5 \%$ ）に大きかった.

一方, 引張試験後の破断面は, DRS おょび TSRでは 接着界面での界面破壊および軟質裏装材層での凝集破壊の 両者が混在する混合破壊を示し，ETH では接着界面での 界面破壊を示した。

\section{2. $\mathrm{AG}$ との接着強さ}

表 3 および図 3 に, 各軟質裏装材と $A G$ との接着強さ の経時的変化を示した.

DRS の接着強さは, 浸漬 1 日後で $1.39 \mathrm{MPa}$ を示した 後増大し, 4 週間後で $1.97 \mathrm{MPa}$ を示した後わずかに減少 する傾向を示した。

対照の ETH の接着強さは, 浸漬 1 日後では $0.02 \mathrm{MPa}$ を示したが, 1 週間後以降では引張試験前に剥離を示し, $0 \mathrm{MPa}$ となった. また, TSRの接着強さは, 経時的に浸 漬 1 日から 8 週間後まで変動が認められ，0.62〜0.81 $\mathrm{MPa}$ を示した。

また, 浸漬 8 週間後での各軟質裏装材の接着強さを比較 すると，DRSのそれが，ETH およびTSRのそれより有 意（危険率 $5 \%$ ）に大きかった。

一方, 引張試験後の破断面は, DRS および TSRでは 接着界面での界面破壊および軟質裏装材層での凝集破壊の 両者が混在する混合破壊を示し, ETH では接着界面での 界面破壊を示した。

\section{3. $\mathrm{CO}$ との接着強さ}

表 3 および図 4 に, 軟質裏装材と $\mathrm{CO}$ との接着強さの経 時的変化を示した.

DRSの接着強さは, 浸漬 1 日後で $1.54 \mathrm{MPa}$ を示した 後増大し, 4 週間後で $2.64 \mathrm{MPa}$ を示した後減少し, 8 週 間後では $1.59 \mathrm{MPa}$ となった。

対照の ETH の接着強さは, 浸漬 1 日後では $0.02 \mathrm{MPa}$ を示したが, 1 週間後以降では引張試験前に剥離を示し, $0 \mathrm{MPa}$ となった. また, TSRの接着強さは, 経時的に浸 漬 1 日から 8 週間後まで変動が認められ，0.40〜0.56 MPaを示した。

また, 浸漬 8 週間後での各軟質裏装材の接着強さを比較 すると, DRSのそれが, ETH およびTSRのそれより有 意（危険率 $5 \%$ ）に大きかった。

一方, 引張試験後の破断面は, DRS およびTSRでは 接着界面での界面破壊および軟質裏装材層での凝集破壊の 両者が混在する混合破壊を示し，ETHでは接着界面での 界面破壊を示した。 
表 3 Tensile bond strength of soft relining materials to denture base materials and results of $\mathrm{t}$-test of means of tensile bond strength after 8 weeks 軟質裏装材と床用材料との接着強さおよび 8 週間後の接着強さの検定結果

\begin{tabular}{|c|c|c|c|c|c|c|c|c|}
\hline \multirow{2}{*}{$\begin{array}{l}\text { Denture } \\
\text { base } \\
\text { material }\end{array}$} & \multirow{2}{*}{$\begin{array}{c}\text { Soft } \\
\text { relining } \\
\text { material }\end{array}$} & \multicolumn{7}{|c|}{ Tensile bond strength $(\mathrm{MPa}) /$ Time } \\
\hline & & 1-day & 1-week & 2-week & 4-week & 6-week & 8-week & \\
\hline \multirow{3}{*}{$18 \mathrm{~K}$} & DRS & $\begin{array}{c}2.05 \\
(0.19)\end{array}$ & $\begin{array}{c}2.14 \\
(0.25)\end{array}$ & $\begin{array}{c}2.08 \\
(0.26)\end{array}$ & $\begin{array}{c}2.85 \\
(0.53)\end{array}$ & $\begin{array}{c}2.75 \\
(0.78)\end{array}$ & $\begin{array}{c}2.75 \\
(0.39)\end{array}$ & \\
\hline & ETH & $\begin{array}{c}0.05 \\
(0.05)\end{array}$ & $\begin{array}{c}0.00 \\
(0.00)\end{array}$ & $\begin{array}{c}0.00 \\
(0.00)\end{array}$ & $\begin{array}{c}0.00 \\
(0.00)\end{array}$ & $\begin{array}{c}0.00 \\
(0.00)\end{array}$ & $\begin{array}{c}0.00 \\
(0.00)\end{array}$ & * \\
\hline & TSR & $\begin{array}{c}0.54 \\
(0.04)\end{array}$ & $\begin{array}{c}0.55 \\
(0.11)\end{array}$ & $\begin{array}{c}0.62 \\
(0.15)\end{array}$ & $\begin{array}{c}0.76 \\
(0.04)\end{array}$ & $\begin{array}{c}0.66 \\
(0.14)\end{array}$ & $\begin{array}{c}0.57 \\
(0.13)\end{array}$ & \\
\hline \multirow{3}{*}{$\mathrm{AG}$} & DRS & $\begin{array}{c}1.39 \\
(0.09)\end{array}$ & $\begin{array}{c}1.42 \\
(0.46)\end{array}$ & $\begin{array}{c}1.49 \\
(0.31)\end{array}$ & $\begin{array}{c}1.97 \\
(0.44)\end{array}$ & $\begin{array}{c}1.86 \\
(0.49)\end{array}$ & $\begin{array}{c}1.76 \\
(0.53)\end{array}$ & \\
\hline & ETH & $\begin{array}{c}0.02 \\
(0.02)\end{array}$ & $\begin{array}{c}0.00 \\
(0.00)\end{array}$ & $\begin{array}{c}0.00 \\
(0.00)\end{array}$ & $\begin{array}{c}0.00 \\
(0.00)\end{array}$ & $\begin{array}{c}0.00 \\
(0.00)\end{array}$ & $\begin{array}{c}0.00 \\
(0.00)\end{array}$ & * \\
\hline & TSR & $\begin{array}{c}0.62 \\
(0.04)\end{array}$ & $\begin{array}{c}0.64 \\
(0.18)\end{array}$ & $\begin{array}{c}0.72 \\
(0.20)\end{array}$ & $\begin{array}{c}0.81 \\
(0.11)\end{array}$ & $\begin{array}{c}0.74 \\
(0.12)\end{array}$ & $\begin{array}{c}0.76 \\
(0.06)\end{array}$ & \\
\hline \multirow{3}{*}{$\mathrm{CO}$} & DRS & $\begin{array}{c}1.54 \\
(0.25)\end{array}$ & $\begin{array}{c}1.57 \\
(0.31)\end{array}$ & $\begin{array}{c}1.76 \\
(0.25)\end{array}$ & $\begin{array}{c}2.64 \\
(0.33)\end{array}$ & $\begin{array}{c}2.10 \\
(0.21)\end{array}$ & $\begin{array}{c}1.59 \\
(0.09)\end{array}$ & \\
\hline & ETH & $\begin{array}{c}0.02 \\
(0.03)\end{array}$ & $\begin{array}{c}0.00 \\
(0.00)\end{array}$ & $\begin{array}{c}0.00 \\
(0.00)\end{array}$ & $\begin{array}{c}0.00 \\
(0.00)\end{array}$ & $\begin{array}{c}0.00 \\
(0.00)\end{array}$ & $\begin{array}{c}0.00 \\
(0.00)\end{array}$ & * \\
\hline & TSR & $\begin{array}{c}0.56 \\
(0.59) \\
\end{array}$ & $\begin{array}{c}0.56 \\
(0.12) \\
\end{array}$ & $\begin{array}{c}0.50 \\
(0.20) \\
\end{array}$ & $\begin{array}{c}0.40 \\
(0.32)\end{array}$ & $\begin{array}{c}0.46 \\
(0.25) \\
\end{array}$ & $\begin{array}{c}0.51 \\
(0.05) \\
\end{array}$ & \\
\hline \multirow{3}{*}{ TI } & DRS & $\begin{array}{c}1.62 \\
(0.45)\end{array}$ & $\begin{array}{c}1.64 \\
(0.32)\end{array}$ & $\begin{array}{c}2.14 \\
(0.47)\end{array}$ & $\begin{array}{c}2.75 \\
(0.45)\end{array}$ & $\begin{array}{c}2.52 \\
(0.47)\end{array}$ & $\begin{array}{c}2.29 \\
(0.48)\end{array}$ & \\
\hline & ETH & $\begin{array}{c}0.03 \\
(0.03)\end{array}$ & $\begin{array}{c}0.02 \\
(0.01)\end{array}$ & $\begin{array}{c}0.00 \\
(0.00)\end{array}$ & $\begin{array}{c}0.00 \\
(0.00)\end{array}$ & $\begin{array}{c}0.00 \\
(0.00)\end{array}$ & $\begin{array}{c}0.00 \\
(0.00)\end{array}$ & * \\
\hline & TSR & $\begin{array}{c}0.67 \\
(0.05)\end{array}$ & $\begin{array}{c}0.73 \\
(0.05)\end{array}$ & $\begin{array}{c}0.75 \\
(0.06)\end{array}$ & $\begin{array}{c}0.78 \\
(0.09)\end{array}$ & $\begin{array}{c}0.66 \\
(0.08)\end{array}$ & $\begin{array}{c}0.56 \\
(0.05)\end{array}$ & \\
\hline \multirow{3}{*}{ PC } & DRS & $\begin{array}{c}1.81 \\
(0.19)\end{array}$ & $\begin{array}{c}2.35 \\
(0.41)\end{array}$ & $\begin{array}{c}2.44 \\
(0.54)\end{array}$ & $\begin{array}{c}2.02 \\
(0.50)\end{array}$ & $\begin{array}{c}2.18 \\
(0.46)\end{array}$ & $\begin{array}{c}2.33 \\
(0.41)\end{array}$ & \\
\hline & ETH & $\begin{array}{c}1.09 \\
(0.18)\end{array}$ & $\begin{array}{c}1.12 \\
(0.22)\end{array}$ & $\begin{array}{c}1.20 \\
(0.25)\end{array}$ & $\begin{array}{c}1.32 \\
(0.30)\end{array}$ & $\begin{array}{c}1.25 \\
(0.26)\end{array}$ & $\begin{array}{c}1.22 \\
(0.07)\end{array}$ & $*$ \\
\hline & TSR & $\begin{array}{c}0.4 \overline{7} \\
(0.10)\end{array}$ & $\begin{array}{c}0.66 \\
(0.07) \\
\end{array}$ & $\begin{array}{c}0.70 \\
(0.11) \\
\end{array}$ & $\begin{array}{c}0.76 \\
(0.50)\end{array}$ & $\begin{array}{c}0.77 \\
(0.17)\end{array}$ & $\begin{array}{c}0.80 \\
(0.10) \\
\end{array}$ & \\
\hline \multirow{3}{*}{ PSF } & DRS & $\begin{array}{c}1.59 \\
(0.37)\end{array}$ & $\begin{array}{c}2.08 \\
(0.59)\end{array}$ & $\begin{array}{c}1.59 \\
(0.37)\end{array}$ & $\begin{array}{c}1.89 \\
(0.52)\end{array}$ & $\begin{array}{c}1.59 \\
(0.43)\end{array}$ & $\begin{array}{c}1.47 \\
(0.20)\end{array}$ & \\
\hline & ETH & $\begin{array}{c}1.08 \\
(0.31)\end{array}$ & $\begin{array}{c}1.37 \\
(0.19)\end{array}$ & $\begin{array}{c}1.30 \\
(0.30)\end{array}$ & $\begin{array}{c}1.06 \\
(0.31)\end{array}$ & $\begin{array}{c}1.10 \\
(0.25)\end{array}$ & $\begin{array}{c}1.12 \\
(0.07)\end{array}$ & $*$ \\
\hline & TSR & $\begin{array}{c}0.61 \\
(0.07)\end{array}$ & $\begin{array}{c}0.83 \\
(0.12)\end{array}$ & $\begin{array}{c}0.75 \\
(0.11)\end{array}$ & $\begin{array}{c}0.72 \\
(0.12)\end{array}$ & $\begin{array}{c}0.75 \\
(0.10)\end{array}$ & $\begin{array}{c}0.74 \\
(0.08)\end{array}$ & \\
\hline
\end{tabular}

\section{TI との接着強さ}

表 3 および図 5 に, 軟質裏装材と TI との接着強さの経 時的変化を示した。

DRSの接着強さは，浸漬 1 日後で $1.62 \mathrm{MPa}$ を示した 後増大し, 4 週間後で $2.75 \mathrm{MPa}$ を示した後減少し, 8 週 間後では $2.29 \mathrm{MPa}$ となっった。

対照の ETH の接着強さは, 浸漬 1 日後および 1 週間後 では $0.02 \sim 0.03 \mathrm{MPa}$ を示したが, 2 週間後以降では引張 試験前に剝離を示し，0 MPa となった。また，TSRの接 着強さは, 経時的に浸漬 1 日から 8 週間後まで変動が認め られ, $0.56 \sim 0.78 \mathrm{MPa}$ を示した。

また，浸漬 8 週間後での各軟質裏装材の接着強さを比較 すると，DRSのそれが，ETH およびTSRのそれより有
意（危険率 $5 \%$ ）に大きかった。

一方, 引張試験後の破断面は, DRS およびTSRでは 接着界面での界面破壊抢よび軟質裏装材層での凝集破壊の 両者が混在する混合破壊を示し，ETH では接着界面での 界面破壊を示した。

\section{PC との接着強さ}

表 3 および図 6 に, 軟質裏装材と PC との接着強さの経 時的変化を示した。

DRSの接着強さは, 浸漬 1 日後で $1.81 \mathrm{MPa}$ を示した 後, 経時的に 8 週間後まで変動が認められ，2.02〜2.44 MPa を示した。

対照の ETH の接着強さは, 浸漬 1 日後で $1.09 \mathrm{MPa}$ を 
表 4 Results of $\mathrm{t}$-test of means of tensile bond strength at each immersion time 各漫清期間後での接着強さ間の $\mathrm{t}$-検定結果

\begin{tabular}{|c|c|c|c|c|c|}
\hline $18 \mathrm{~K}$-DRS & 1-week & 2-week & 4-week & 6-week & 8-week \\
\hline 1-day & - & - & - & - & $*$ \\
\hline 1-week & & - & - & - & - \\
\hline 2-week & & & - & - & * \\
\hline 4-week & & & & - & - \\
\hline 6-week & & & & & - \\
\hline $18 \mathrm{~K}-\mathrm{ETH}$ & 1-week & 2-week & 4-week & 6-week & 8-week \\
\hline 1-day & - & - & - & - & - \\
\hline 1-week & & - & - & - & - \\
\hline 2-week & & & 一 & - & - \\
\hline 4-week & & & & - & - \\
\hline 6-week & & & & & - \\
\hline $18 \mathrm{~K}-\mathrm{TSR}$ & 1-week & 2-week & 4-week & 6-week & 8-week \\
\hline 1-day & - & - & $*$ & - & - \\
\hline 1-week & & - & $*$ & - & - \\
\hline 2-week & & & - & - & - \\
\hline 4-week & & & & - & $*$ \\
\hline 6-week & & & & & - \\
\hline AG-DRS & 1-week & 2-week & 4-week & 6-week & 8-week \\
\hline 1-day & - & - & $*$ & - & - \\
\hline 1-week & & - & - & - & - \\
\hline 2-week & & & - & - & - \\
\hline 4-week & & & & - & - \\
\hline 6-week & & & & & - \\
\hline AG-ETH & 1-week & 2-week & 4-week & 6-week & 8-week \\
\hline 1-day & - & - & - & - & - \\
\hline 1-week & & - & - & - & - \\
\hline 2-week & & & - & - & - \\
\hline 4-week & & & & - & - \\
\hline 6-week & & & & & - \\
\hline AG-TSR & 1-week & 2-week & 4-week & 6-week & 8-week \\
\hline 1-day & - & - & $*$ & - & $*$ \\
\hline 1-week & & - & - & - & - \\
\hline 2-week & & & - & - & - \\
\hline 4-week & & & & - & - \\
\hline 6-week & & & & & - \\
\hline CO-DRS & 1-week & 2-week & 4-week & 6-week & 8-week \\
\hline 1-day & - & - & * & $*$ & - \\
\hline 1-week & & - & $*$ & $*$ & - \\
\hline 2-week & & & $*$ & - & - \\
\hline 4-week & & & & - & $*$ \\
\hline 6-week & & & & & $*$ \\
\hline CO-ETH & 1-week & 2-week & 4-week & 6-week & 8-week \\
\hline 1-day & - & - & - & - & - \\
\hline 1-week & & - & - & - & - \\
\hline 2-week & & & - & - & - \\
\hline 4-week & & & & - & - \\
\hline 6-week & & & & & - \\
\hline CO-TSR & 1-week & 2-week & 4-week & 6-week & 8-week \\
\hline 1-day & - & - & - & - & - \\
\hline 1-week & & - & - & - & - \\
\hline 2-week & & & - & - & - \\
\hline 4-week & & & & - & - \\
\hline 6-week & & & & & - \\
\hline
\end{tabular}

\begin{tabular}{cccccc}
\hline \hline TI-DRS & 1-week & 2-week & 4-week & 6 -week & 8 -week \\
\hline 1-day & - & - & $*$ & - & - \\
1-week & & - & $*$ & $*$ & - \\
2-week & & & - & - & - \\
4-week & & & & - & - \\
6-week & & & & & - \\
\hline
\end{tabular}

\begin{tabular}{cccccc}
\hline \hline TI-ETH & 1-week & 2-week & 4-week & 6 -week & 8-week \\
\hline 1-day & - & - & - & - & - \\
1-week & & - & - & - & - \\
2-week & & & - & - & - \\
4-week & & & & - & - \\
6-week & & & & & - \\
\hline
\end{tabular}

\begin{tabular}{cccccc}
\hline \hline TI-TSR & 1-week & 2-week & 4 -week & 6 -week & 8 -week \\
\hline 1-day & - & - & - & - & - \\
1-week & & - & - & - & - \\
2-week & & & - & - & - \\
4-week & & & & - & - \\
6-week & & & & & - \\
\hline \hline PC-DRS & 1-week & 2-week & 4-week & 6 -week & 8 -week \\
\hline 1-day & - & - & - & - & - \\
1-week & & - & - & - & - \\
2-week & & & - & - & - \\
4-week & & & & - & - \\
6-week & & & & & - \\
\hline
\end{tabular}

\begin{tabular}{cccccc}
\hline \hline PC-ETH & 1-week & 2-week & 4-week & 6-week & 8 -week \\
\hline 1-day & - & - & - & - & - \\
1-week & & - & - & - & - \\
2-week & & & - & - & - \\
4-week & & & & - & - \\
6-week & & & & & - \\
\hline
\end{tabular}

\begin{tabular}{|c|c|c|c|c|c|}
\hline PC-TSR & 1-week & 2-week & 4-week & 6-week & 8-week \\
\hline 1-day & $*$ & $*$ & - & $*$ & $*$ \\
\hline 1-week & & - & - & - & - \\
\hline 2-week & & & - & - & - \\
\hline 4-week & & & & - & - \\
\hline 6-week & & & & & - \\
\hline PSF-DRS & 1-week & 2-week & 4-week & 6-week & 8-week \\
\hline 1-day & - & - & - & - & - \\
\hline 1-week & & - & - & - & - \\
\hline 2-week & & & - & - & - \\
\hline 4-week & & & & - & - \\
\hline 6-week & & & & & - \\
\hline
\end{tabular}

\begin{tabular}{cccccc}
\hline \hline PSF-ETH & 1-week & 2-week & 4-week & 6 -week & 8 -week \\
\hline 1-day & - & - & - & - & - \\
1-week & & - & - & - & - \\
2-week & & & - & - & - \\
4-week & & & & - & - \\
6-week & & & & & - \\
\hline \hline PSF-TSR & 1-week & 2-week & 4 -week & 6 -week & 8 -week \\
\hline 1-day & $*$ & - & - & - & - \\
1-week & & - & - & - & - \\
2-week & & & - & - & - \\
4-week & & & & - & - \\
6-week & & & & & - \\
\hline
\end{tabular}

*: difference was significant $(p<0.05)$

- : difference was not significant $(p>0.05)$ 


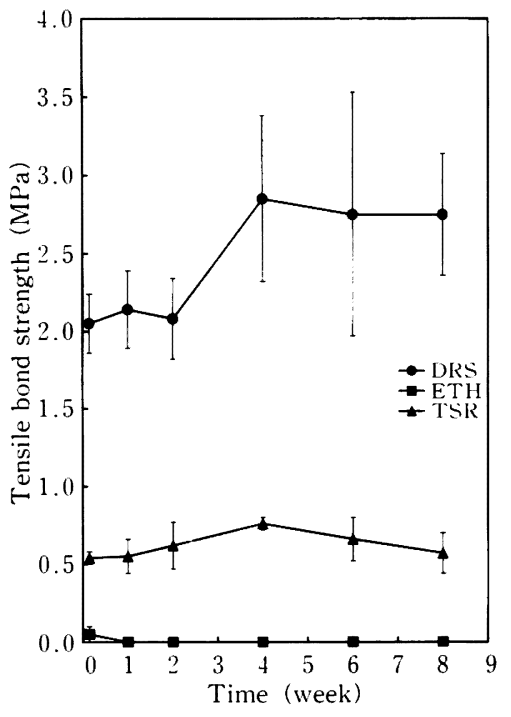

図 2 Tensile bond strength of soft relining materials to $18 \mathrm{~K}$ gold alloy $(18 \mathrm{~K})$

軟質裹装材と $18 \mathrm{~K}$ 金合金 $(18$ K) との接着強さ

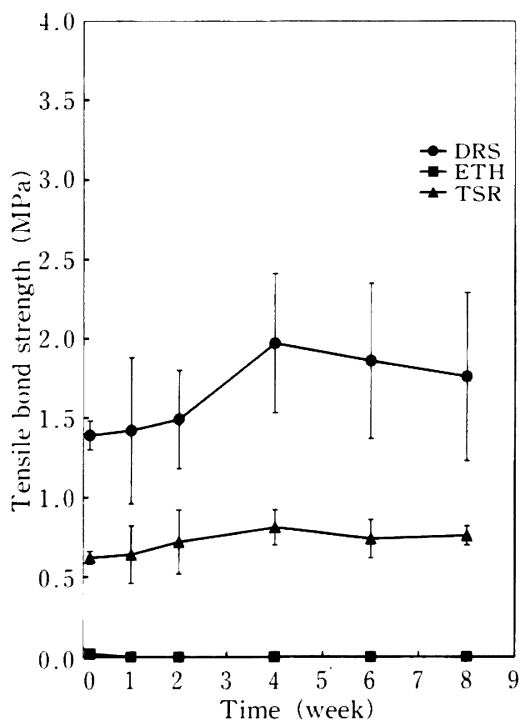

图 3 Tensile bond strength of soft relining materials to $\mathrm{Ag}-\mathrm{Pd}-\mathrm{Au}$ alloy (AG)

欶質裏装材と金銀パラジウム合金 (AG) との接着強さ

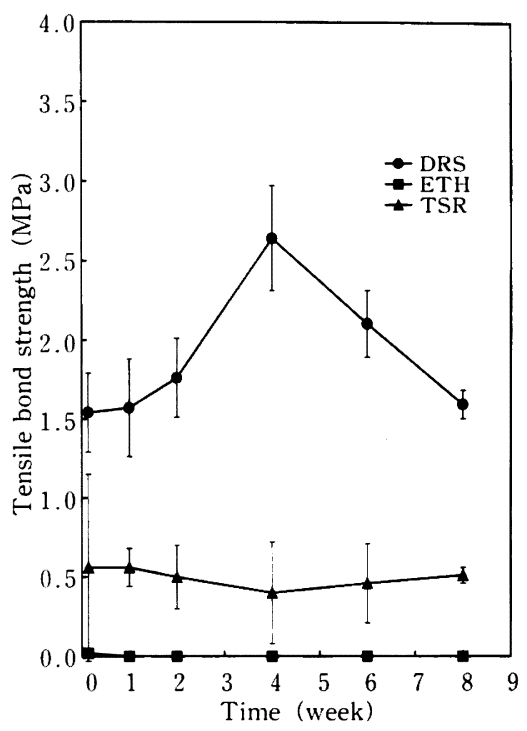

図 4 Tensile bond strength of soft relining materials to $\mathrm{Co}-\mathrm{Cr}$ alloy $(\mathrm{CO})$

軟質裏装材と $\mathrm{Co}-\mathrm{Cr}$ 合金 $(\mathrm{CO})$ との接着強さ

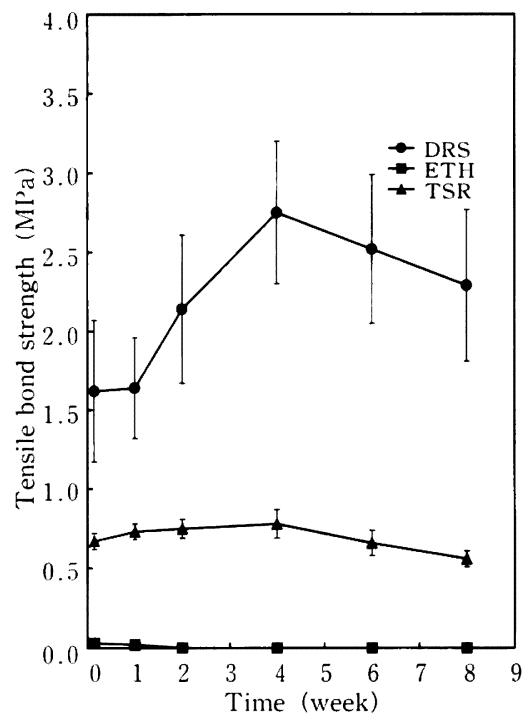

図 5 Tensile bond strength of soft relining materials to titanium (TI)

硕質襄装材とチタン（TI）との 接着強さ

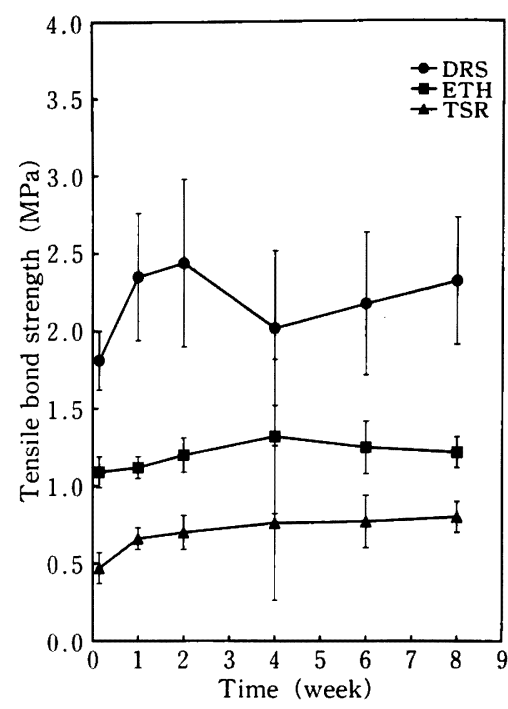

図 6 Tensile bond strength of soft relining materials to polycar. bonate resin (PC) 軟質裏装材とポリカーボネートレ ジン (PC) との接着強さ

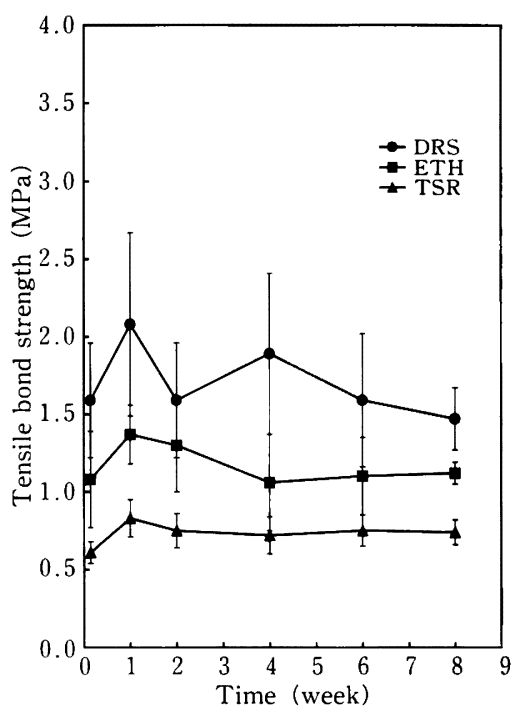

図 7 Tensile bond strength of soft relining materials to polysul. fone resin (PSF) 㳄質袈装材とポリサルホンレジン (PSF) との接着強さ
示した後経時的に 8 週間後まで変動が認められ，1.12〜 $1.32 \mathrm{MPa}$ を示した。また, TSRの接着強さは, 浸漬 1 日後で $0.47 \mathrm{MPa}$ を示した後, 経時的にわずかに増大する 傾向を示し, 8 週間後では $0.80 \mathrm{MPa}$ を示した。

また，浸漬 8 週間後での各軟質裏装材の接着強さを比較 すると，DRSのそれが，ETH およびTSRのそれより有 意（危険率 $5 \%$ ）に大きかった。
一方, 引張試験後の破断面は, 3 種の軟質裏装材いずれ でも，ほとんどが軟質裏装材層の凝集破壊を示し，一部で 混合破壊を示した。

\section{PSF との接着強さ}

表 3 および図 7 に, 軟質裏装材とPSF との接着強さの 経時的変化を示した。 
DRS の接着強さは，浸漬 1 日後で $1.59 \mathrm{MPa}$ を示した 後, 経時的に 8 週間後まで変動が認められ, 1.47〜2.08 $\mathrm{MPa}$ を示した。

対照の ETH の接着強さは, 浸漬 1 日後で $1.08 \mathrm{MPa}$ 示した後, 経時的に 8 週間後まで変動が認められ，1.06〜 $1.37 \mathrm{MPa}$ を示した. また, TSR では, 接着強さは浸漬 1 日後で $0.61 \mathrm{MPa}$ を示した後, 1 週間後で $0.83 \mathrm{MPa}$ とわ ずかに増大し，それ以降では $0.72 〜 0.75 \mathrm{MPa}$ のほほ一定 値を示した。

また, 浸漬 8 週間後での各軟質裏装材の接着強さを比較 すると, DRSのそれが, ETH およびTSRのそれより有 意（危険率 5\%）に大きかった.

一方, 引張試験後の破断面は, 3 種の軟質裏装材いずれ でも，ほとんどが軟質裏装材層の凝集破壊を示し，一部で 混合破壊を示した.

\section{IV. 考 察}

シリコーンラバー系軟質裏装材と義歯床用アクリルレジ ンとの接着性が不十分であるとの多くの指摘 ${ }^{2,9,15 \sim 18)}$ から， これまでは，その改善に努力が払われてきた。このような 背景から，アクリルレジン以外の床用材料とこの種の軟質 裏装材との接着についてはほとんど検討されていなかっ た。

著者らは, 前報 ${ }^{19)} て ゙$ 新規シリコーンラバー系軟質裏装材 デンチャーリライニングと義歯床用レジンとの初期接着強 さおよび接着強さの経時的変化を検討した結果, 初期接着 強さは在来品と比較して $1.4 \sim 2.4$ 倍と大きく, また, 接 着耐久性が良好で，5 力月後での接着強さは在来品の 2.3 〜3.2 倍と大きいことを明らかにした。これは，主として 材質が改善されて軟質裏装材の引張および引裂強さが大き くなったこと, さらに, 製品付属のプライマーの表面改質 効果が大きかったためと考察した.

そこで, 本研究では, シリコーンラバー系軟質裏装材と 4 種の床用金属および 2 種の床用レジンとの接着性につい て検討した。

\section{1. 軟質裏装材と床用金属との接着強さについて}

DRS と床用金属 4 種との接着強さ（図 2～5）は，経時 的に浸漬 4 週間までは増大し，その後はほとんど変化しな い群（18 K と AG）と減少する群 (CO と TI) とがあっ た.これは, DRS 自体の引張および引裂強さが経時的に 増大する ${ }^{19}$ 効果と, 接着界面に浸入した水分によって接着 界面での接着強さが低下する効果とが拮抗したためと考え られた。

前報19)では，DRSと義歯床用アクリルレジン（以下 PMMA）との接着強さについて検討したが，引張試験後 の破断面は DRS 層での凝集破壊であり，接着界面での接
着強さの低下はほとんど観察されなかった：それと比較す ると, 本研究での破断面は混合破壊を示し, 界面での接着 強さの低下が顕著に現れたものと考えられた。したがっ て, プライマーの床用材料に対する表面改質効果は, PMMA に対するそれと比較して床用金属 4 種ではいずれ も小さかったものと考えられた。

一方, 対照の ETH では, 床用金属 4 種との接着強さは 浸漬 1 日後で 0.02〜0.05 MPa と非常に小さく，1〜2週 間後では $0 \mathrm{MPa}$ となって, 引張試験以前に界面剥離を示 していた。これは，ETHに付属のプライマーが床用金属 の表面改質には有効でないためと考えられた。また， TSR では, 床用金属 4 種との接着強さは浸漬 1 日後で $0.54 \sim 0.67 \mathrm{MPa}$ を示した後, 経時的に若干変動して, 浸 漬 8 週間後で 0.51〜0.67 MPa であったが，これらの値は DRSのそれの 1/2〜1/5 と小さかった。これは, 主として TSR の引張および引裂強さが DRSのそれと比較して小 さい(19)たと考えられた. 試験後の破断面はDRSの場合 と同様に混合破壊を呈していたことから，TSRに付属の プライマーも床用金属に対する表面改質効果がわずかだっ たものと考えられた.

\section{2. 軟質裏装材と床用レジンとの接着強さについて}

DRS と床用レジン 2 種との接着強さ（図 6,7）は, 経 時的に変動し $1.47 〜 2.44 \mathrm{MPa}$ を示したが, いずれの浸漬 期間での接着強さ間にも有意差がなく（表 4), ほとんど 変化しないものと考えられた。しかし, 引張試験後の破断 面は, 前報 ${ }^{19)}$ の PMMA ではすべての試験体で DRS 層で の凝集破壊であったものが，PC および PSFでは一部の 試験体で混合破壊を生じていたことから，製品付属のプラ イマーのPCおよびPSFに対する表面改質効果は, PMMA に対するそれより小さかったものと考えられた。 したがって，界面部から浸入した水分によって，界面部で の接着強さが低下し, 破壊様式に一部混合破壊が生じたも のと考えられた。

一方，対照の ETH では，床用レジン 2 種との接着強さ は，経時的にわずかに変動して $1.06 〜 1.37 \mathrm{MPa}$ を示した が, いずれの浸漬期間での接着強さ間にも有意差がなく, ほとんど変化しないものと考えられた。しかし, 引張試験 後の破断面にDRSの場合と同様に一部の試験体に混合破 壊を生じていることから, 製品付属のプライマーの PC お よびPSFに対する表面改質効果は，PMMA に対するそ れより小さかったものと考えられた。ここで得られた接着 強さは, DRSのそれの1/2〜4/5 と小さかった.これは， 主として ETH 自体の引張および引裂強さが DRS のそれ より小さい(19)ためと考えられた。

TSR では, 床用レジン 2 種との接着強さは, 浸漬 1 日 後で $0.47 \sim 0.61 \mathrm{MPa}$ を示した後, 浸漬 1 または 2 週間後 には有意に増大して $0.66 〜 0.83 \mathrm{MPa}$ となったが，それ以 
降ではいずれの浸漬期間での接着強さ間にも有意差がな く，ほとんど変化しないものと考えられた. しかし，引張 試験後の破断面にDRS および ETH の場合と同様に一部 の試験体に混合破壊を生じていることから，製品付属のプ ライマーのPC および PSF に対する表面改質効果は, PMMAに対するそれより小さかったものと考えられた。 ここで得られた接着強さは, DRS および ETH と比較し て最も小さいものであった。これは，TSR 自体の引張お よび引裂強さが DRS およびETHのそれより小さい(19)た めと考えられた。

\section{3. プライマーの表面改質効果について}

前報 ${ }^{191}$ では，軟質裏装材と PMMA との接着強さを測定 し，接着強さと軟質裏装材自体の引張および引裂強さとの 関係について検討したが, 接着強さは軟質裏装材の引張お よび引裂強さの両者と正の相関を示すことを明らかとし た。また，これらの接着試験体では，引張試験後の破断面 がいずれも軟質裏装材の凝集破壊であり，接着強さが軟質 董装材自体の引張強さにほほ一致していた。このことは, DRS，ETH およびTSRに付属のプライマーは，PMMA に対しては表面改質効果が十分で軟質裏装材との接着に有 効に作用し，長期間の耐久性を与えていたものと考えられ た。

これに対し，本研究の床用金属との接着では, DRSお よびTSR で得られた接着強さは軟質裏装材自体の引張強 さ19)より小さく，また，引張試験後の破断面が混合破壊を 呈していた。このことは，製品付属のプライマーは，床用 金属に対する表面改質効果が十分であるとはいえないが， かなり有効に作用していたものと考えられた。しかし， ETH では，プライマーの床用金属に対する表面改質効果 はほとんどないものと判断された。

次に, 本研究の床用レジン（PC および PSF）との接着 では，得られた接着強さはそれぞれ 3 種の軟質裏装材自体

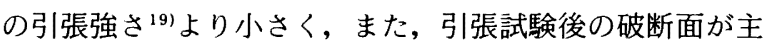
として軟質裏装材層の凝集破壊を，一部混合破壊を呈して いた。

この破壊様式からは, 製品付属のプライマーの床用レジ ン（PC および PSF）に対する表面改質効果は，PMMA に対するそれより大きくはないものの，床用金属 4 種に対 するそれよりは大きいものと考えられた。

以上総合すると，シリコーンラバー系軟質裏装材と床用 金属および床用レジンとの接着では，軟質裏装材の引張強 さの大きさおよび軟質裏装材付属のプライマーの床用材料 に対する表面改質効果が大きいほど接着強さが大きくなる ことが明らかとなった。 また，軟質裏装材 DRS と床用金 属 4 種および床用レジン 2 種に対する接着強さは, 在来品 と比較していずれの組合せでも大きいことが明らかとなっ た.さらに,プライマーの表面改質効果の向上が期待された。

\section{V. 結 論}

口腔内での耐久性の改善を図ったとされる新規シリコー ンラバー系軟質裏装材デンチャーリライニング（ソフトタ イプ：DRS）と床用金属 4 種（18 K 金合金：18 K, 金銀 パラジウム合金：AG，コバルトクロム合金：CO および チタン：TI）および床用レジン 2 種（ポリカーボネー 卜：PC およびポリサルホン：PSF）との接着強さの経時 的変化を測定して，その有用性について検討した．その結 果, 以下の結論を得た。

\section{1. 床用金属との接着強さ}

1） DRS と床用金属 4 種との接着強さは，浸漬 1 日後 で1.39〜2.05 MPa を示した後, 浸漬 4 週間後まで増加し て $1.97 〜 2.85 \mathrm{MPa}$ を示し，その後はほとんど変化しない 群（18 K および $\mathrm{AG})$ と減少する群（COおよび $\mathrm{TI} ）$ と があり, 浸漬 8 週間後で 1.59〜2.75 MPa を示した.

2）DRS と床用金属 4 種との接着強さを，在来品 2 種 のそれと比較すると, 浸漬 8 週間後での值ではいずれも DRSのそれが有意に大きかった。

3） DRS と床用金属 4 種との接着試験体の引張試験後 の破断面は，DRSの凝集破壊および界面破壊が混合した 混合破壊を示した。

\section{2. 床用レジンとの接着強さ}

1）DRS と床用レジン 2 種との接着強さは，浸漬 1 日 後で 1.59 1.81 MPa を示した後, 経時的に変動が認めら れ，1.47〜2.44 MPa を示したが，いずれの浸漬期間での 接着強さ間にも有意差がなかった。

2） DRS と床用レジン 2 種との接着強さを，在来品 2 種のそれと比較すると, 浸漬 8 週間後での値ではいずれも DRSのそれが有意に大きかった。

3） DRS と床用レジン 2 種との接着試験体の引張試験 後の破断面は，主として DRSの凝集破壊を示し，一部に 混合破壊を示した。

\section{3. プライマーの表面改質効果}

DRS 付属のプライマーの表面改質効果は, 床用レジン 2 種（PC およびPSF）に対してでは，PMMAに対して の効果より小さく，また，床用金属に対してではさらに小 さかった. しかし，在来品 2 種に付属のプライマーより表 面改質効果は大きいものと判断された.

本研究の一部は日本大学歯学会平成 9 年度大会 (平成 9 年 11 月 29，30 日，松戸）および 76 th General Session \& Exhibition of the IADR（June 24〜27, 1998, Nice）において発表した. 


\section{文献}

1) Lammie GA, Storer R. A preliminary report on resilient denture plastics. J Prosth Dent 8: 411-424, 1958.

2) Storer R. Resilient denture base materials Part 2, Clinical trial. Br Dent J 113:231-239, 1962.

3) Bates JF, Smith DC. Evaluation of indirect resilient liners for dentures: laboratory and clinical tests. J Am Dent Assoc $70: 344-353,1965$.

4）平安亮造，今村真悟，岡田修造ほか。弾性襄装材一Silastic 390 Soft Liner一に上る臨床的効果. 補緅誌 $10: 79-87,1965$.

5) Parker HM. Impact reduction in complete and partial dentures A pilot study. J Prosth Dent 16:227-245, 1966.

6) Plotnick IJ. Stress regulator for complete and partial dentures. J Prosth Dent $17: 166-171,1967$.

7）都留宏道，大川周治，関根秀明ほか．フレンジテクニックを応 用した後に軟質裹装材クレペートを使用して咀緭機能を回復し た総義歯の一症例. 補綴誌 $26: 55-62,1982$.

8) Schmidt WF. Smith DE. A six-year retrospective study of Molloplast-B-lined dentures Part I : Patient response. J Prosthet Dent $50: 308-313,1983$.

9) Schmidt WF, Smith DE. A six-year retrospective study of Molloplast-B-lined dentures Part II : Liner serviceability. J Prosthet Dent $50: 459-464,1983$.

10) Nishiyama M, Kato T. Properties of LTV vinyl silicone rubber-based resilient denture base liners and directions for use. J Nihon Univ Sch Dent $29: 100-111,1987$.

11）都留宏道，長澤 亨，大川周治ほか。新しい義歯床用軟質裏装 材「モルテノ」の臨床評価. 歯科技工 $15: 519-525,1987$.

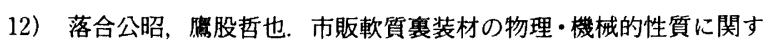
る基礎的検討一初期物性について一。補緅誌 $38: 383-390$, 1994.

13）河野文昭，長尾 寛，野田正純ほか，軟質裹装材の衝㧘緩衝に 関する研究 第 2 報 裹装法の違いが衝整緩衝能に与える影 響. 補緅誌 $40: 501-507,1996$.

14）西村文夫. 軟質裏装材 義歯安定剤の理工学的性質. 日本歯科 医師会器材調査委員会報告, 東京：日本歯科医師会, 1997.

15) Woelfel JB, Paffenbarger GC. Evaluation of complete dentures lined with resilient silicone rubber. J Am Dent Assoc $76: 582-590,1968$

16) Means CR, Rupp NW, Paffenbarger GC. Clinical evaluation of two types of resilient liners on dentures. J Am Dent Assoc $82: 1376-1380,1971$.

17) Wright PS. The success and failure of denture soft-relining materials in clinical use. J Dent $12: 319-327,1984$.

18) Wright PS. A three year longitudinal study of denture soft relining materials in clinical use. Clin Mater 1:281-289, 1986.

19）西山 實, 廣瀬英晴, 大木一三ほか。新しいシリコーンラバー 系軟質裏装材デンチャーリライニングの物性と接着性につい て. 補緅誌 $41: 796-803,1997$.

著者連絡先：廣瀬 英晴

厂101-8310＼cjkstart東京都千代田区神田駿河台 1-8 $-13$

TEL $\quad 03-3219-8127$

FAX 03-3219-8342

E-mail hirose-h@dent.nihon-u.ac.jp 